\title{
The Uses of Race and Religion: James Baldwin's Pragmatist Politics in The Fire Next Time
}

\author{
Courtney Ferriter Auburn University
}

\begin{abstract}
In The Fire Next Time, James Baldwin argues that the American dream is far from being a reality in part because there is much Americans do not wish to know about themselves. Given the current political climate in the United States, this idea seems just as timely as it did in the 1960s. Baldwin's politics and thinking about race and religion are informed by an optimistic belief in the human capacity to love and change for the better, in contrast with Ta-Nehisi Coates, the heir apparent to Baldwin's legacy. Considering current events, it seems particularly useful to turn back to The Fire Next Time. Not only does Baldwin provide a foundation for understanding racism in the United States, but more importantly, he provides some much-needed hope and guidance for the future. Baldwin discusses democracy as an act that must be realized, in part by coming to a greater understanding of race and religion as performative acts that have political consequences for all Americans. In this article, I examine the influence of pragmatism on Baldwin's understanding of race and religion. By encouraging readers to acknowledge race and religion as political constructs, Baldwin highlights the inseparability of theory and practice that is a hallmark of both pragmatism and the realization of a democratic society. Furthermore, I argue that Baldwin's politics provide a more useful framework than Coates's for this particular historical moment because of Baldwin's emphasis on change and evolving democracy.
\end{abstract}

Keywords: James Baldwin, Fire Next Time, pragmatism, democracy, Ta-Nehisi Coates

In his 1963 volume The Fire Next Time, James Baldwin observes that African Americans are well placed to "[b] ring down the curtain on the American dream." For Baldwin, the American dream is far from being a reality because "there are too

James Baldwin Review, Volume 2, 2016 @ The Authors. Published by Manchester University Press and The University of Manchester Library 
many things we do not wish to know about ourselves" (p. 88). Given the current political climate in the United States, Baldwin's statements seem just as timely now as they did in the 1960s. Indeed, the rise of the Black Lives Matter movement, widely publicized protests in Ferguson, MO, and Baltimore, MD, in the wake of the killings of Michael Brown and Freddie Gray, and a renewed focus in the media on police brutality against African Americans provide proof of Baldwin's claims, making him particularly relevant to a current discussion of race relations in the United States.

To be black in the United States today is a precarious existence at best. In his 2015 book Between the World and Me, Ta-Nehisi Coates tells his son Samori that "the police departments of [this] country have been endowed with the authority to destroy your body," and furthermore, "In America, it is traditional to destroy the black body-it is heritage" (p. 103, emphasis in original). Coates, who grew up in Baltimore, has been involved in journalism since the early 2000s and achieved greater fame and renown once he began writing for The Atlantic in 2008. He is currently one of the best-known black public intellectuals writing in the U.S., and has often been compared to James Baldwin. Coates wrote Between the World and $\mathrm{Me}$ as a letter to his son, the same conceit Baldwin used in The Fire Next Time, wherein Baldwin's letter is to his nephew. In fact, Coates was inspired to write his recent book after re-reading The Fire Next Time.

In her review of Between the World and Me for The New York Times, Michelle Alexander suggests that one major difference between Coates and Baldwin lies in their views of the future. She writes that Baldwin "repeatedly emphasizes [his nephew's] power and potential and urges him to believe that revolutionary change is possible against all odds." 3 Coates, on the other hand, emphasizes "the apparent permanence of racial injustice in America, the foolishness of believing that one person can make a change, and the dangers of believing in the American Dream."4 Indeed, in his letter Coates encourages his son to "resist the common urge toward the comforting narrative of divine law, toward fairy tales that imply some irrepressible justice" because "the birth of a better world is not ultimately up to you" (pp. 70, 71). He argues that "there is nothing uniquely evil" about the numerous police killings of unarmed black men and women and expresses his sadness for Americans who continue to "[revel] in a specious hope" (p. 10). He even alludes to and revises Martin Luther King, Jr.s 1967 "Where Do We Go from Here?" speech, writing that his own "understanding of the universe was physical, and its moral arc bent toward chaos then concluded in a box" (p. 28). Coates concludes that one of the "preferences of the universe itself [is] struggle over hope" (p. 71), and he remarks that African Americans are in fact "called to struggle, not because it assures you victory, but because it assures you an honorable and sane life" (p. 97). Between the World and Me presents a pessimistic view of American society overall; Coates holds out no hope that current racial injustices will change because he has seen the same injustices since his youth. Above all, he is fearfulunderstandably so-for his son's future.

Baldwin, on the other hand, emphasizes the possibility for positive change and 
growth throughout The Fire Next Time. He does this whether he is considering the human capacity for morality_ "we must believe that it is possible" (p. 47, emphasis in original) and "I know that people can be better than they are" (p. 91)-or African-American history as a whole, which, for Baldwin, "testifies to nothing less than the perpetual achievement of the impossible" (p. 104). Although Baldwin would agree with Coates on "the fact that life is tragic" and that "birth, struggle, and death are constant" (pp. 91, 92), Baldwin adds that love and the ability to change are constants as well; love and change as constants are concepts noticeably absent from Coates's understanding of the United States, despite his acknowledgment that "love [is] an act of heroism" (p. 61).

Ultimately, the most pronounced distinction between Baldwin and Coates is Baldwin's emphasis on love and growth as opposed to Coates's emphasis on fear and stasis. This distinction between love and fear is one Coates himself makes, writing that he "grew up in a house drawn between love and fear" (p. 61). Coates repeatedly highlights his fears in Between the World and Me. Early in the book, he tells his son, "I am afraid. I feel the fear most acutely whenever you leave me. But I was afraid long before you, and in this I was unoriginal" (p. 14). In his description of growing up in Baltimore, Coates reveals that he was "a capable boy, intelligent, well-liked, but powerfully afraid" (p. 28). At the end of Between the World and Me, he drives home after a visit with Mabel Jones and observes familiar ghettos- "the same ghettos I had seen in Chicago all those years ago, the same ghettos where my mother was raised, where my father was raised" (pp. 151-2)-and the sight of their landmarks causes him to "[feel] the old fear" (p. 152). On the subject of love, Coates tells his son, "Your mother had to teach me how to love you [...] Even now it does not feel a wholly natural act so much as it feels like ritual. And that is because I am wounded. That is because I am tied to old ways, which I learned in a hard house" (pp. 125-6). Coates laments that he would like to believe that "such a day approaches when the people who believe themselves to be white renounce this demon religion and begin to think of themselves as human. But I can see no real promise of such a day." Baldwin casts love as an antidote to fear and links love with growth in The Fire Next Time. He argues,

Love takes off the masks that we fear we cannot live without and know we cannot live within. I use the word 'love' here not merely in the personal sense but as a state of being, or a state of grace-not in the infantile American sense of being made happy but in the tough and universal sense of quest and daring and growth. (p. 95)

Coates's view of the world and certainly of democracy in the United States seems fixed, unwilling to acknowledge the possibility for societal change or even the capacity for individuals to change and evolve over time. This stands in direct contrast to Baldwin's view that as our country and its people progress and evolve, we move toward love, openness, and a more inclusive democracy.

Considering the regular violence against black bodies and the rise of social activism in the form of the Black Lives Matter movement, it seems particularly useful to 
turn back to Baldwin's volume The Fire Next Time. Not only does Baldwin provide a philosophical foundation for understanding the problems and racial tensions that continue to plague the United States to this day, but he also provides some much-needed hope and guidance for the future. This is a time of both struggle and change, despair and love. Some readers may object that considering Baldwin in light of current events provides at best an antiquated solution to present problems. Nevertheless, I maintain that Coates's pessimism and recurring emphases on fear provide a reason to turn back to Baldwin, because Baldwin offers a feasible solution toward which we can all work: expanding democracy via Deweyan pragmatism.

While Baldwin's work is often read with a focus on the intersections of sexuality, race, or religion in mind, significantly less scholarly attention has been paid to the link between Baldwin's ideas about race and religion and pragmatist philosophy. Reading Baldwin as a pragmatist helps illuminate his views of race and religion in The Fire Next Time, in which he describes both concepts as tools to be used practically and beneficially. Baldwin discusses democracy as an act that must be realized, in part by coming to a greater understanding of race as a construct that has political consequences for all American citizens. "Color is not a human or a personal reality; it is a political reality" (p. 104), he writes. Similarly, he argues with respect to religion that "if the concept of God has any validity or use, it can only be to make us larger, freer, and more loving” (p. 47). In this essay, I examine the influence of pragmatism on Baldwin's understanding of race and religion. First, I discuss Baldwin's connections to earlier pragmatist thinkers who influenced his philosophy. I then examine how Baldwin's understanding of race and religion shape his thinking about democracy in The Fire Next Time. By encouraging readers to acknowledge race and religion as political acts, Baldwin ultimately highlights the inseparability of theory and practice that is a hallmark of both pragmatism and the realization of a democratic society.

While Baldwin did not specifically align himself with pragmatist thinkers or philosophy, his work was influenced by Alain Locke and W. E. B. Du Bois, both of whom were influenced in their thinking by William James, who popularized pragmatist philosophy in the United States. Ulf Schulenberg argues that much of Baldwin's thought reflects "a genealogy of black pragmatism that reaches from W. E. B. Du Bois and Alain Locke to [Cornel] West." Baldwin's philosophy also shares important similarities with that of John Dewey, another influential figure in pragmatist thought. Dewey and Baldwin both thought of democracy as participatory and as an ever-evolving process.

W. E. B. Du Bois became a student of William James at the time when James was developing his pragmatist philosophy. Truth, James wrote later in his book Pragmatism, "is not a stagnant property inherent" in an idea; rather, an idea "becomes true, is made true by events." For Du Bois, the idea that democracy is not stagnant but something that has yet to be realized in America was a powerful notion. "This much all men know," he wrote in The Souls of Black Folk, "despite compromise, war, and struggle, the Negro is not free." ${ }^{10}$ Here Du Bois takes 
William James's notion that truth happens to an idea and applies it to democracy, affirming that democracy is experiential. In other words, the only way to know that democracy is working is to apply its method: everyone's voice gets a chance to be heard. Although Du Bois made this observation about democracy in 1903, sixty years later Baldwin likewise wrote of a democracy still not fully realized in the lives of African Americans. Baldwin tells his nephew that "the root of my dispute with [this] country" is that "you were born where you were born and faced the future that you faced because you were black and for no other reason" (p. 7, emphasis in original). Baldwin alludes to democracy as an action that must be realized when he tells his nephew, "You know, and I know, that the country is celebrating one hundred years of freedom one hundred years too soon" (p. 10). African Americans might be free in the legal sense of emancipation from slavery, but they do not enjoy all of the same legal rights as whites, given the widespread occurrence of segregation, redlining, and other discriminatory policies. Baldwin's observation is that white people's alleged beliefs and actions are not aligned where democracy for African Americans is concerned-whites profess a belief in democracy, but only for themselves, not for all Americans-and thus, they are failing to apply the democratic method.

Baldwin was also interested in anti-essentialism in the vein of the pragmatist thinker Alain Locke. Locke argues in his essay "The Concept of Race as Applied to Social Culture" that race and culture are social constructs that have been misused by scientists to promote racist ideology at the expense of empirical data and knowledge. ${ }^{11}$ Locke's thinking on this issue was shaped by William James, who argued that the pragmatist "turns away ... from bad a priori reasons, from fixed principles, closed systems, and pretended absolutes and origins"12 toward concrete facts. Likewise, Baldwin's claim in The Fire Next Time- "I did not intend to allow the white people of this country to tell me who I was, and limit me that way, and polish me off that way" (pp. 23-4)-demonstrates a similar commitment to turning away from fixed systems and limited ways of thinking. Such closed systems promote the notion that truth is stagnant and unchanging, whereas James, Locke, Baldwin, and Dewey all believed in the experiential and evolving nature of truth.

Baldwin has been linked to Dewey, particularly Dewey's philosophy of democracy. Walton Muyumba argues that Baldwin's work "is intellectually related to John Dewey's call for the radicalization of American democracy." ${ }^{13}$ Muyumba suggests that, according to Baldwin, Americans could "achieve radical democracy by learning to improvise narratives of self-becoming that also communicate what John Dewey calls the American 'great community."'14 Dewey argues in The Public and Its Problems for a distinction between "society" and "community." Society arises from the politics of individual nations, how a particular country governs and what political policies are enforced, whereas community is unrestricted and made up of diverse groups that share a common solidarity. ${ }^{15}$ When Baldwin discusses the conditions in which African Americans live in The Fire Next Time, he argues, "Black people, mainly, look down or look up, but do not look at each other, not at you, and white people, mainly, look away" (p. 30). In this passage, Baldwin points to 
the fact that this type of society is anti-Deweyan; there is no great community-no solidarity between different groups of Americans-and thus, there is no realized democracy.

Taken together, these comparisons between Baldwin and leading pragmatist philosophers suggest that even if Baldwin did not consider himself a pragmatist thinker, his writing was nevertheless aligned with several important pragmatist figures, and thus, his work may be usefully illuminated by reading it through a pragmatist lens. These thinkers all share a sense of ideas and knowledge as evolving. For pragmatists, the meaning of a term like "democracy" evolves over time to reflect experience and changing understanding of the world. Furthermore, understandings of identity and racial identity also evolve, testing and undermining essentialist ideas. Finally, communities and ideas about community evolve as new members, new groups, and new ideas are integrated into a community's pre-existing experience. One benefit of pragmatism is that it does not foreclose possibilities, and like his pragmatist influences, Baldwin felt that the concepts of race and religion should be open to any necessary or useful modifications, particularly because an evolving understanding of these concepts has the potential to make the United States more open, inclusive, and democratic.

Scholars who include Baldwin in a black pragmatist genealogy cite his views of race as a distinctly pragmatist feature of his work. In his 1998 book Color and Culture, Ross Posnock argues that identity politics as practiced by blacks and whites alike has long been "fixated on racial difference and the question of what and who is authentically black." ${ }^{16}$ Posnock reads Baldwin as resisting the otherwise "homogenous norms"17 enforced by traditional identity politics, suggesting that "for a black intellectual like Baldwin, complexity-resistance to racial identity-is, say in The Fire Next Time, precisely the means to achieve more nuanced modes of political engagement." ${ }^{18}$ In other words, as opposed to black Muslim intellectuals or pan-Africanist activists who promote a vision of black identity as essentialized or unified, Baldwin sees race as complex and evolving. Walton Muyumba cites the experimentation and improvisation present in Baldwin's fiction as embracing "the ambiguities of [black] consciousness while exposing paths out of trauma and away from essentialized masculine and black identities." 19 He understands Baldwin as promoting what he calls a 'thin' notion of African-American identity that "neither insists on an essentialist notion of [black] identity nor promotes individual experience at the expense of political hope. ${ }^{20}$ In short, Baldwin's views of race and racial identity are not fixed; instead, he recognizes that race is a shifting construct and a political tool, and for this reason, the perception of race directly affects democracy in the United States.

Baldwin highlights the dangers of essentialized views of race in The Fire Next Time, for both black and white people alike, for ultimately race in the United States is an imaginary projection that nevertheless has all too real and serious consequences. He writes, "The American Negro is a unique creation; he has no counterpart anywhere, and no predecessors" (p. 84). Similarly, he observes, "Negroes do not, strictly or legally speaking, exist in any other [country]" (p. 25). Baldwin 
understands the figure of the "American Negro" as a creation of white Americans, and this white notion of racialized identity has distinctly negative consequences for both groups. He tells his nephew James that white people "have had to believe for many years, and for innumerable reasons, that black men are inferior to white men. Many of them, indeed, know better, but, as you will discover, people find it very difficult to act on what they know [...] In this case, the danger, in the minds of most white Americans, is the loss of their identity" (pp. 8-9). Baldwin calls white people's essentialized views of race and identity a "collection of myths" (p. 101). Included among these myths is the idea that white people's ancestors "were all freedom-loving heroes [...] that American men are the world's most direct and virile, that American women are pure" (p. 101). According to Christopher Freeburg, Baldwin suggests that black identity is "never stable, which forces whites to erect new and better fictions and social strictures alike to keep the Negro cogent and intact." ${ }^{21}$ Recall here William James's caution for pragmatists to turn away from "bad a priori reasons, from fixed principles [and] closed systems." 22 This fixed, closed system of belief in the idea of the "American Negro" and of "whiteness" as good and pure enables whites to cling to the myth of innate racial superiority. However, Baldwin knows that this system of thinking also hinders them from acceptance of themselves as well as achievement of the democratic ideal of equality. On this point, Baldwin writes, "White people in this country will have quite enough to do in learning how to accept and love themselves and each other, and when they have achieved this [...] the Negro problem will no longer exist, for it will no longer be needed" (p. 22). He suggests that to dismantle the accumulated myths of whiteness and blackness, both of which rely on an understanding of essentialized identity, will ultimately result in a more loving and inclusive society.

The danger of essentialized racial identity for black Americans is that their physical lives are at stake as well as their emotional and spiritual lives. Baldwin cites his father as an example of someone who had "a terrible life" and was "defeated long before he died because, at the bottom of his heart, he really believed what white people said about him" (p. 4). If African Americans internalize the white concept of the "American Negro," then they will likely feel defeated, as Baldwin's father did, believing that nothing can be done to change who they are and how they are perceived. Baldwin sees through this fiction and advocates for a change in perception among black people. He suggests that all black people in the United States "are taught really to despise themselves from the moment their eyes open on the world" (p. 25), and for this reason he encourages his nephew to "take no one's word for anything, including mine-but trust your experience" (p. 8).

In spite of the ugliness with which whites treat black people and black identity in the form of the "American Negro," Baldwin does not believe that the solution for African Americans is to reject the United States or to adopt polar opposite viewpoints from whites with respect to their understanding of black identity. He writes, "the Negro has been formed by this nation, for better or for worse, and does not belong to any other" (p. 81). As far as color is concerned, he warns, "one must be careful not to take refuge in any delusion-and the value placed on the color 
of the skin is always and everywhere and forever a delusion" (p. 104). Because white people hold an entrenched, essentialized view of color, black people must be cautious against adhering to the same system of understanding with opposite implications. In white consciousness, white is good and black is bad, and Baldwin reasons that we will not progress as a society if black Americans merely attempt to reverse this paradigm to one of black is good and white is bad. ${ }^{23} \mathrm{He}$ explains, "as long as we in the West place on color the value that we do, we make it impossible for the great unwashed to consolidate themselves according to any other principle" (pp. 103-4). Elevating blackness over whiteness would only serve to reinforce the significance of color to society. Baldwin believes our societal emphasis on color is particularly tragic, since the United States, "of all the Western nations, has been best placed to prove the uselessness and the obsolescence of the concept of color" (p. 93). If the United States is truly the democracy it claims to be, then the nation must align its beliefs with its practice by affirming everyone's rights and elevating no one group above the others. Thus, the use of race for Baldwin-its political reality-is to change the negative practical consequences of a constructed idea, ideally and ultimately resulting in a de-emphasis on color as a central identifier in society. This shift in perception among whites and blacks alike would result in a more democratic and inclusive society.

In The Fire Next Time the Christianity of Baldwin's childhood shares the entrenched and essentialized qualities that Baldwin faults in many Americans' understanding of racial identity. Baldwin observes a clear discrepancy between the Christian ideals that people presume to hold and their real-life actions. He writes that for many white people, "neither civilized reason nor Christian love would cause any of those people to treat you as they presumably wanted to be treated" (p. 21). Likewise, he argues that "virtues preached but not practiced by the white world were merely another means of holding Negroes in subjection" (p. 23). White Christians may preach the virtues of compassion and love for their fellow man, but Baldwin notes that black people in his community "did not have to be abnormally sensitive to be worn down" (p. 19) by the constant humiliation and danger they faced on a daily basis from whites, who all the while professed themselves good Christians. He also discusses the hypocrisy he observed at work in his own religious community, where God existed "only within the walls of a churchin fact, of our church" (p. 16). In both black and white churches, Christian beliefs are not aligned with people's actions. Baldwin mentions that in his own church, the ministers expected him to succeed them in the future, and as such, they were waiting for him to realize that he was "in a very lucrative business" (p. 38) where he could eventually expect to acquire "houses and Cadillacs" (p. 39) with the money of faithful congregants, even though many of those same congregants were barely able to provide for their own families.

In The Varieties of Religious Experience, William James discusses the concept of the divided self, which results from the non-alignment of a person's beliefs and actions. When religiously minded people fail to practice what they preach, James argues, then "unhappiness will take the form of moral remorse and compunction, 
of feeling inwardly vile and wrong, and of standing in false relations to the author of one's being and appointer of one's spiritual fate [...] man's interior is a battleground for what he feels to be two deadly hostile selves, one actual, the other ideal." ${ }^{4}$ Baldwin observes a divided self similar to what James describes at work in overly pious Christians. ${ }^{25}$ He suggests, "the passion with which we loved the Lord was a measure of how deeply we feared and distrusted and, in the end, hated almost all strangers, always, and avoided and despised ourselves" (p. 41). The failure to uphold the virtues of Christian love and charity results in a self that fanatically loves the Almighty but hates oneself-a Jamesian ideal self in conflict with an actual self. Baldwin goes on to argue that people's "inability to renew themselves at the fountain of their own lives" (p. 43) results in a fundamental self-loathing and distrust. This causes real-world problems, since "the person who distrusts himself has no touchstone for reality" (p. 43).

Because of hypocrisy and divided selfhood, Baldwin concludes that with respect to promoting morality, "the role of Christianity has been, at best, ambivalent" (p. 46). For this reason, in order for all people to become more moral-to align their theoretical beliefs and practical actions-they must "divorce [themselves] from all the prohibitions, crimes, and hypocrisies of the Christian church" (p. 47). James writes in Pragmatism that true beliefs are those that prove to be good-good in the sense of useful or beneficial- "and good, too, for definite, assignable reasons."26 Baldwin seems to apply a similar logic to his consideration of Christianity, arguing that if "the concept of God has any validity or use, it can only be to make us larger, freer, and more loving. If God cannot do this, then it is time we got rid of Him" (p. 47). Thus, for Baldwin, the use of Christianity should be to make people more open to others and to align belief with practice, rather than remaining entrenched in their fixed, closed system of belief in the supremacy or correctness of their own church or way of thinking.

Baldwin is likewise critical of the Nation of Islam (NOI) in The Fire Next Time for promoting an essentialized way of thinking about race and religion, even as it speaks more directly to the black experience in the U.S. He describes Elijah Muhammad's address to African-American crowds in Harlem, noting that Muhammad "did not need to prove to a Harlem audience that all white men were devils. They were merely glad to have, at last, divine corroboration of their experience. .." (p. 50). Baldwin's point here is that NOI doctrine justifies and validates the pre-existing views of many African Americans, conclusions that they have reached based on their own experience of the world. In this case, years of oppression and white supremacy easily lends itself to the conclusion that white people are evil. Baldwin writes to his nephew James that he must trust his own experience, and for this reason he is sympathetic to black people who turn to Islam. In fact, Baldwin writes that when he met Elijah Muhammad, he felt "drawn toward his peculiar authority, how his smile promised to take the burden of my life off my shoulders" (p. 64), so it is not difficult for him to see the appeal of such a figure. Having already discussed how "the Christian world has revealed itself as morally bankrupt" (p. 51), Baldwin argues that African Americans who take refuge in Islam do so because, 
according to NOI, "God is black. All black men belong to Islam; they have been chosen" (p. 57). NOI repudiated the Christian view long-used to justify slavery that descendants of Ham were cursed and their lot was to serve the white man, suggesting instead that all people were initially black and perfect and that in fact it is white people who are "cursed, and are devils, and are about to be brought down" (p. 49). According to Baldwin, whites are depicted in NOI accounts as literal devils created through a series of "infernal experiments" (p. 67) which the black God Allah had never approved. Here Baldwin observes that NOI is proof that religion is used as an instrumental tool. He argues that some African Americans have concluded that "the best that God (the white God) can do" is not enough, and thus, "it is time to replace Him" (p. 57). Baldwin suggests that African-American converts to Islam reason that "the white God has not delivered them [so] perhaps the Black God will" (p. 57). Rather than continuing to adhere to the Christian religion, whose beliefs white people do not put into practice, many black people have turned to a religion that elevates their status while prophesying the evils and end of white supremacy.

At his meeting with Elijah Muhammad, it does not take long for Baldwin to realize that "Elijah's power came from his single-mindedness" (p. 66). Like the essentialist view of race symbolized in the figure of the "American Negro," Baldwin recognizes a black Muslim version of white nationalist rhetoric in NOI theology. This belief system holds that there is "by definition, no virtue in white people, and since they are another creation entirely and can no more, by breeding, become black than a cat, by breeding, can become a horse, there is no hope for them" (p. 67). Baldwin goes on to say that "there is nothing new in this merciless formulation except the explicitness of its symbols and the candor of its hatred. Its emotional tone is as familiar to me as my own skin" (p. 67). Such religious beliefs attempt to shift the racial paradigm to an essentialized view of race in which black is good and white is bad. Exchanging white Christianity for black Islam only serves to promote a worldview in which color is still the most important defining quality.

Again, Baldwin is not unsympathetic to this point of view; he fully understands its appeal. That white people are devils for whom there is no hope is a stance he believes to be "abundantly justified by American Negro history" (p. 73). However, Baldwin's understanding of religion as a belief system that should ultimately make people more open and more loving cannot abide the closed, essentialist NOI beliefs that put color front and center in order to elevate African Americans and to demonize white people. As he sits with Elijah Muhammad, Baldwin wonders “'isn't love more important than color?"' (p. 71). Simultaneously Baldwin acknowledges that people "always seem to band together in accordance to a principle that has nothing to do with love, a principle that releases them from personal responsibility" (p. 81).

Baldwin had hopes for the push toward Islam among African Americans and believed that it had the potential for beneficial use. He thought it might be able "to inculcate in the demoralized Negro population a truer and more individual sense of its own worth" (p. 81) so that African Americans would be empowered 
to change their situation. However, he adds that in order to change one's situation "one has first to see it for what it is: in the present case, to accept the fact [...] that the Negro has been formed by this nation, for better or for worse, and does not belong to any other-not to Africa, and certainly not to Islam" (p. 81). In order to use their past for good, African Americans must first accept it. For Baldwin, the best possible outcome of using black people's past in the United States would be "transcendence of the realities of color, of nations, and of altars" (p. 82). By contrast, the essentialist racial message spread by NOI would eventually result in violence, Baldwin argues. On this point, he writes, "The glorification of one race and the consequent debasement of another-or others-always has been and always will be a recipe for murder. There is no way around this" (p. 82). This does not result in a more open, more loving, or more democratic society, for "whoever debases others is debasing himself" (p. 83, emphasis in original). Baldwin learned this lesson as a child in his own Christian community, which promoted the love of the Lord, but disdain for those who did not share their particular vision of faith. This resulted in a divided self and internalized self-loathing. Thus, "for their dignity, for the health of their souls," Baldwin argues that he cannot support any movement among his fellow African Americans "to do to others what has been done to them" (p. 83).

Henry Louis Gates, Jr. has said of Baldwin that if he had "a central political argument, it was that the destinies of black America and white were profoundly and irreversibly intertwined. Each created the other, each defined itself in relation to the other, each could destroy the other." ${ }^{27}$ Such an argument is particularly evident in The Fire Next Time. Toward the end of the volume, Baldwin writes, "In short, we, the black and the white, deeply need each other here if we are really to become a nation-if we are really, that is, to achieve our identity, our maturity, as men and women" (p. 97). Baldwin, like fellow pragmatist John Dewey, understands democracy as an action that must be realized. As a nation, we must continually verify our democracy to ensure that it endures and expands, and the key to realizing democracy is to become always more inclusive-to be vigilant regarding the rights of others and to be daring enough to love one another as Baldwin hopes in The Fire Next Time. Baldwin connects love with growth, and our democracy must likewise be open to growth and change rather than mired in old ways of thinking about ideas. To think of race, for example, as a simplified and unchanging black/white binary, or religion as an "us vs. them" conflict between the in-group and the outsiders, endangers democracy in the United States and fosters fear rather than love.

Baldwin admits that there is "no possibility of a real change in the Negro's situation without the most radical and far-reaching changes in the American political and social structure" (p. 85). However, he also insists that "American Negro history ... testifies to nothing less than the perpetual achievement of the impossible" (p. 104). In these uncertain and trying times for black Americans, all Americans would do well to take to heart Baldwin's insights on race and religion and his optimistic outlook for the future if we are to help our country realize the 
democratic ideals for which we claim to stand. One way of accomplishing this goal is to be vigilant, as Baldwin was, against essentialist rhetorics or politics of any kind. It is easy to become swept up in over-simplified, closed systems of thinking-for example, the now-prevalent notion parroted by politicians that Islam represents a danger to Western civilization or that Muslims should be banned from entering the United States-but the pragmatist method, like the democratic method, encourages openness, pluralism, and inclusivity. Baldwin encourages love where there is hatred or fear, and this kind of love has the potential to unify rather than further divide. Applying Baldwin's pragmatist politics in light of current racial struggles and tensions in the United States is not the easy solution, but it is the solution of love and change, two things Americans could use more of at present.

\section{Notes}

1 James Baldwin, The Fire Next Time (1963) (New York, Vintage, 1993), p. 88. All subsequent quotations are taken from this edition. Page numbers are given in parentheses in the text.

2 Ta-Nehisi Coates, Between the World and Me (New York, Spiegel and Grau, 2015), p.9. All subsequent quotations are taken from this edition. Page numbers are given in parentheses in the text.

3 Michelle Alexander, "Ta-Nehisi Coates's 'Between the World and Me," The New York Times, Sunday Book Review, 17 August 2015, par. 8, http://www.nytimes.com/2015/08/17/ books/review/ta-nehisi-coates-between-the-world-and-me.html.

$4 \mathrm{Ibid}$, par. 9.

5 In this speech, King paraphrased abolitionist Theodore Parker's statement "The arc of the moral universe is long, but it bends toward justice."

6 Ta-Nehisi Coates, "Letter to My Son," Atlantic, 316:2 (2015), p. 90.

7 Ulf Schulenburg, "'Speaking Out of the Most Passionate Love-James Baldwin and Pragmatism," European Journal of American Studies, 2:2 (2007), p. 3.

8 William James, Pragmatism (1907) (Cambridge, MA, Harvard University Press, 1975), p. 97.

9 Ibid. Emphasis in original.

10 W. E. B. Du Bois, The Souls of Black Folk (1903) (New York, Dover Publications, 1994), p. 24 .

11 For full argument, see Alain Locke, "The Concept of Race as Applied to Social Culture," in L. Harris (ed.), The Philosophy of Alain Locke: Harlem Renaissance and Beyond (Philadelphia, PA, Temple University Press, 1989), pp. 187-99.

12 James, Pragmatism, p. 31.

13 Walton Muyumba, "All Safety Is an Illusion': John Dewey, James Baldwin, and the Democratic Practice of Public Critique," in Brian Jackson and Gregory Clark (eds.), Trained Capacities: John Dewey, Rhetoric, and Democratic Practice (Columbia, S.C., University of South Carolina Press, 2014), p. 160.

14 Walton Muyumba, The Shadow and the Act: Black Intellectual Practice, Jazz Improvisation, and Philosophical Pragmatism (Chicago, University of Chicago Press, 2009), p. 92.

15 John Dewey, The Public and Its Problems: An Essay in Political Inquiry (1927), ed. Melvin L. Rogers (University Park, PA, Penn State University Press, 2012), p. 141. 
16 Ross Posnock, Color and Culture: Black Writers and the Making of the Modern Intellectual (Cambridge, MA, Harvard University Press, 1998), p. 3.

17 Ibid.

18 Ibid., p. 8.

19 Muyumba, The Shadow and the Act, p. 103.

20 Ibid., p. 7.

21 Christopher Freeburg, "James Baldwin and the Unhistoric Life of Race," South Atlantic Quarterly, 112:2 (2013), p.231.

22 James, Pragmatism, p. 31.

23 I am not suggesting here that this reversal of the standard racial equation, in which blackness is now considered good and whiteness considered bad, conflicts in any way with the notion of "Black is beautiful." Like the recent Black Lives Matter movement, the idea that "black is beautiful" attempts to bring attention and dignity to African Americans who have long been denied it because of white supremacy. Baldwin has no quarrel with highlighting and celebrating blackness. What he takes issue with in The Fire Next Time is elevating blackness while simultaneously condemning whiteness (as the Nation of Islam does, for example). This is simply the reverse of what white people have done to black people for years and creates a hierarchy based on exclusion rather than fostering inclusion and openness as Baldwin desires.

24 William James, The Varieties of Religious Experience (1902) (Cambridge, MA, Harvard University Press, 1985), pp. 142-3.

25 The Jamesian divided self is distinct from Du Bois's concept of African-American double-consciousness, although both notions share the feature of warring ideals within an individual. James describes a non-alignment of a person's religious beliefs with his actions, which results in an ideal version of the self that adheres to one's religious beliefs and the actual version, which often deviates from his moral and ethical principles. Du Boisian double-consciousness refers to the ability of African Americans to see themselves as they are seen through the eyes of whites so that they constantly feel the 'twoness' of being simultaneously American and black.

26 James, Pragmatism, p. 42.

27 H. L. Gates, Jr., “The Fire Last Time,” New Republic 206:22 (1992), p. 40.

\section{Works Cited}

Alexander, Michelle, “Ta-Nehisi Coates's 'Between the World and Me," New York Times Sunday Book Review, 17 August 2015, http://www.nytimes.com/2015/08/17/books/ review/ta-nehisi-coates-between-the-world-and-me.html (accessed 27 October 2015).

Baldwin, James, The Fire Next Time (1963) (New York, Vintage, 1993).

Coates, Ta-Nehisi, Between the World and Me (New York, Spiegel and Grau, 2015).

"Letter to My Son," Atlantic, 316:2 (2015), pp. 82-91.

Dewey, John, The Public and Its Problems: An Essay in Political Inquiry (1927), ed. Melvin L. Rogers (University Park, PA, Penn State University Press, 2012).

Du Bois, W. E. B, The Souls of Black Folk (1903) (New York, Dover Publications, 1994).

Freeburg, Christopher, "James Baldwin and the Unhistoric Life of Race," The South Atlantic Quarterly, 112:2 (2013), pp.221-39.

Gates, Jr., Henry Louis, “The Fire Last Time,” New Republic, 206:22 (1992), pp.37-43.

James, William, Pragmatism (1907) (Cambridge, MA, Harvard University Press, 1975). 
The Varieties of Religious Experience (1902) (Cambridge, MA, Harvard University Press, 1985).

Locke, Alain, "The Concept of Race as Applied to Social Culture," in L. Harris (ed.), The Philosophy of Alain Locke: Harlem Renaissance and Beyond (Philadelphia, PA, Temple University Press, 1989), pp. 187-99.

Muyumba, Walton, “All Safety Is an Illusion': John Dewey, James Baldwin, and the Democratic Practice of Public Critique," in Brian Jackson and Gregory Clark (eds.), Trained Capacities: John Dewey, Rhetoric, and Democratic Practice (Columbia, S.C., University of South Carolina Press, 2014), pp. 159-73.

The Shadow and the Act: Black Intellectual Practice, Jazz Improvisation, and Philosophical Pragmatism (Chicago, University of Chicago Press, 2009).

Posnock, Ross, Color and Culture: Black Writers and the Making of the Modern Intellectual (Cambridge, MA, Harvard University Press, 1998).

Schulenberg, Ulf, "'Speaking Out of the Most Passionate Love'-James Baldwin and Pragmatism," European Journal of American Studies, 2:2 (2007), pp. 1-16.

\section{Contributor's Biography}

Courtney Ferriter is a Ph.D. candidate at Auburn University. Her research interests include twentieth-century Jewish American and African American literature and American pragmatism. Her dissertation traces a lineage of twentieth-century Jewish American pragmatist figures and examines their philosophical and literary contributions toward shaping a pragmatist identity politics and a more inclusive democratic community. She is currently at work on an article that examines racial types in Gertrude Stein's novella "Melanctha." 